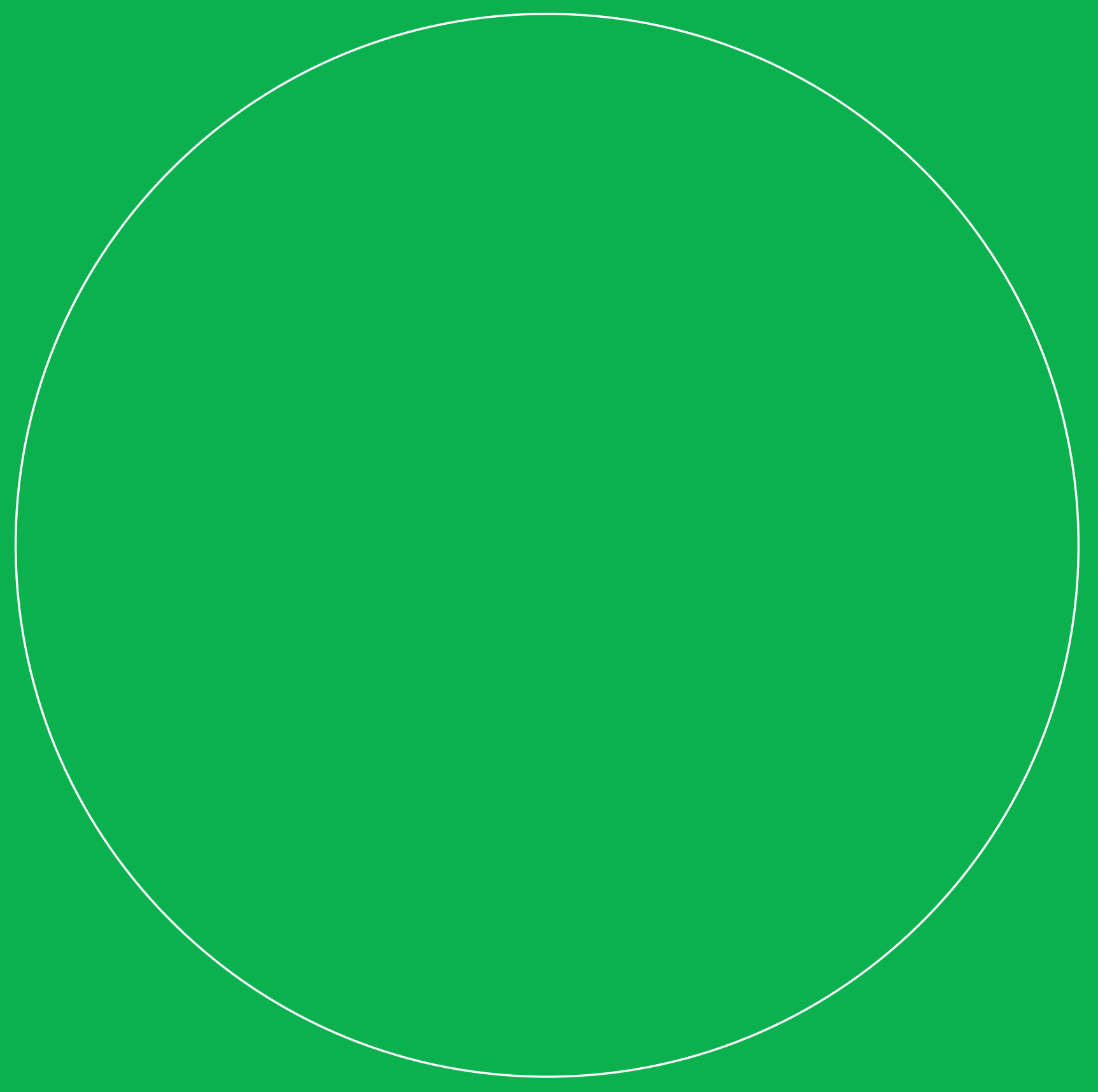

Toegang tot wandelpaden in beheer bij boeren en andere particuliere eigenaren: buitenlandse voorbeelden

Piet Rijk, Ida Terluin en Bas Breman 


\section{Toegang tot wandelpaden in beheer bij boeren en andere particuliere eigenaren: buitenlandse voorbeelden}

Piet Rijk, Ida Terluin en Bas Breman 
Rijk, Piet, Ida Terluin en Bas Breman, 2016. Toegang tot wandelpaden in beheer bij boeren en andere particuliere eigenaren: buitenlandse voorbeelden. Wageningen, Wageningen Economic Research, Nota 2016-095. 18 blz.; 0 fig.; 0 tab.; 7 ref.

Dit rapport is gratis te downloaden op http://dx.doi.org/10.18174/394043 of op www.wur.nl/economic-research (onder Wageningen Economic Research publicaties).

(C) 2016 Wageningen Economic Research

Postbus 29703, 2502 LS Den Haag, T 07033583 30, E communications.ssg@wur.nl, www.wur.nl/economic-research. Wageningen Economic Research is onderdeel van Wageningen University \& Research.

\section{(cc) BY-NC}

Wageningen Economic Research hanteert voor haar rapporten een Creative Commons Naamsvermelding 3.0 Nederland licentie.

(C) Wageningen Economic Research, onderdeel van Stichting Wageningen Research, 2016 De gebruiker mag het werk kopiëren, verspreiden en doorgeven en afgeleide werken maken. Materiaal van derden waarvan in het werk gebruik is gemaakt en waarop intellectuele eigendomsrechten berusten, mogen niet zonder voorafgaande toestemming van derden gebruikt worden. De gebruiker dient bij het werk de door de maker of de licentiegever aangegeven naam te vermelden, maar niet zodanig dat de indruk gewekt wordt dat zij daarmee instemmen met het werk van de gebruiker of het gebruik van het werk. De gebruiker mag het werk niet voor commerciële doeleinden gebruiken.

Wageningen Economic Research aanvaardt geen aansprakelijkheid voor eventuele schade voortvloeiend uit het gebruik van de resultaten van dit onderzoek of de toepassing van de adviezen.

Wageningen Economic Research is ISO 9001:2008 gecertificeerd. 


\section{Inhoud}

1

$\begin{array}{ll}\text { Inleiding } & \mathbf{5}\end{array}$

2

België $\quad 6$

2.1 Organisatie $\quad 6$

$\begin{array}{ll}2.2 & \text { Leerpunten voor Nederland }\end{array}$

$\begin{array}{llr}3 & \text { Duitsland } & 8\end{array}$

3.1 Organisatie $\quad 8$

$\begin{array}{ll}3.2 & \text { Leerpunten voor Nederland }\end{array}$

4

$\begin{array}{ll}\text { Frankrijk } & 10\end{array}$

$\begin{array}{lll}4.1 & \text { Organisatie } & 10\end{array}$

4.2 Leerpunten voor Nederland 11

$5 \quad$ Verenigd Koninkrijk $\quad 12$

5.1 Organisatie $\quad 12$

5.2 Leerpunten voor Nederland 13

$\begin{array}{lrr}6 & \text { Besluit } & 14\end{array}$

$\begin{array}{ll}\text { Literatuur, websites en geraadpleegde personen } & 15\end{array}$

$\begin{array}{ll}\text { Bijlage } 1 \text { Motie Jacobi c.s. (33 } 888 \text { nr. 8) } & 17\end{array}$ 



\section{$1 \quad$ Inleiding}

In het Nederlandse wandelnetwerk wordt in veel wandelroutes gebruik gemaakt van onverharde paden, die veelal in beheer zijn bij particuliere eigenaren. Tussen 2006 en 2011 konden boeren, die een wandelpad over hun land openstelden voor wandelaars, in aanmerking komen voor een vergoeding van $€ 0,45$ per meter pad in het kader van de landelijke Boerenlandpadregeling. Door de decentralisatie van het natuurbeleid werd deze Rijksregeling na 2011 stopgezet. Van de 12 provincies in Nederland hebben er zeven besloten om de regeling voort te zetten, waarbij de vergoeding per provincie kan variëren. Medio 2015 was er ongeveer $750 \mathrm{~km}$ boerenlandpad in gebruik (Haeften, 2015). De Tweede Kamer is van mening dat de huidige regeling om de toegang tot boerenlandpaden te organiseren niet optimaal functioneert en op punten kan worden verbeterd, en heeft daarom in 2015 de Motie Jacobi c.s. (33 888 nr. 8; zie Bijlage) aangenomen. In die motie wordt de regering onder meer verzocht om aan de hand van buitenlandse voorbeelden te onderzoeken in welke vorm de toegankelijkheid van paden in beheer bij boeren en andere particuliere eigenaren het beste in Nederland kan worden georganiseerd.

Doel van deze notitie

Voor de uitvoering van de Motie Jacobi c.s. heeft het ministerie van Economische Zaken Wageningen Economic Research (voorheen: LEI Wageningen UR) en Wageningen Environmental Research (voorheen: Alterra Wageningen UR) benaderd om het gevraagde onderzoek te doen. Deze notitie richt zich op de volgende twee onderzoeksvragen:

1. Hoe is de toegankelijkheid van wandelpaden in beheer bij boeren en andere particuliere eigenaren georganiseerd in het buitenland?

2. Wat kan Nederland daarvan leren voor de organisatie van de toegang tot de Nederlandse wandelpaden?

De studie is gebaseerd op literatuuronderzoek, raadpleging van websites, en schriftelijke en/of telefonische informatie van betrokkenen bij het wandelpadenbeleid in het buitenland. In deze studie is het buitenland beperkt tot de volgende vier EU-lidstaten: België, Duitsland, Frankrijk en het Verenigd Koninkrijk. Deze landen zijn gekozen omdat hun land- en tuinbouwstructuur lijkt op die van Nederland, hoewel hun bedrijfsvoering vaak wel minder intensief is. Verder behandelen we vanwege het quick scan-karakter van de studie alleen de hoofdlijnen rond de toegankelijkheid van wandelpaden.

\section{Opbouw}

In de hoofdstukken 2-5 wordt de organisatie van de toegang tot paden in beheer bij boeren en andere particuliere eigenaren in achtereenvolgens België, Duitsland, Frankrijk en het Verenigd Koninkrijk besproken. Daarbij wordt in elk hoofdstuk aangegeven wat Nederland van het betreffende land kan leren. In het laatste hoofdstuk worden conclusies getrokken en aanbevelingen gedaan. 


\section{België}

\subsection{Organisatie}

In België kunnen wandelaars gebruik maken van de zogenaamde 'trage wegen'. Dat zijn wegen met een openbaar karakter die in hoofdzaak bedoeld en geschikt zijn voor niet-gemotoriseerd verkeer zoals wandelaars, fietsers en ruiters (Clays, 2014). Daarbij houdt het 'openbaar karakter' in dat de weg publiek wordt gebruikt. Administratiefrechtelijk kan het om openbare of particuliere wegen gaan. Er worden vijf verschillende soorten trage wegen onderscheiden (Clays, 2014):

1. Buurtwegen

Buurtwegen zijn van oudsher onverharde paden tussen dorpen, steden en/of landerijen. Veel buurtwegen zijn inmiddels verhard. In de Wet op de Buurtwegen uit 1841 zijn deze wegen erkend en afgebakend. Gemeenten zijn verplicht om deze wegen vast te leggen in een atlas van buurtwegen. Op een buurtweg bestaat de publiekrechtelijke erfdienstbaarheid van doorgang: de weg is voor het publiek toegankelijk. Buurtwegen kunnen het eigendom van de gemeente of een particulier zijn.

2. Gemeentewegen

Gemeentewegen zijn kleine (i.e. lokale) wegen met publiekrechtelijke erfdienstbaarheid van doorgang die geen buurtweg zijn en die eigendom van de gemeente zijn. Deze wegen worden niet in een atlas vastgelegd.

3. Publiekrechtelijke erfdienstbaarheden

Dit zijn wegen in particulier eigendom die door 30-jarige verjaring een publieke erfdienstbaarheid van doorgang hebben gekregen. Ook deze wegen worden niet in een atlas vastgelegd.

4. Wegen in feitelijke toestand van openbare weg

In deze groep vallen wegen waarvan de particuliere eigenaar het publiek gebruik toelaat of gedoogt. Als de eigenaar dit langer dan 30 jaar toestaat, kan deze weg vanwege 30-jarige verjaring in categorie (3) gaan vallen en de status van weg met publiekrechtelijke erfdienstbaarheid van doorgang krijgen.

5. Private wegen

Wegen in particulier eigendom waar het publiek gedurende een beperkte tijd wordt toegelaten. Van deze wegen wordt vaak gebruikt gemaakt om een doorgaande verbinding in een wandelknooppuntennetwerk of recreatieve route te creëren bij gebrek aan andere trage wegen. Bij het geven van de toestemming voor publiek gebruik bedingt de eigenaar van de weg vaak een clausule dat door dit publieke gebruik geen publiekrechtelijke erfdienstbaarheid van doorgang door verjaring kan ontstaan. Bij private wegen kan het gaan om wandelpaden over boerenland. België kent geen regeling voor een beloning voor boeren die paden over boerenland voor het publiek openstellen. Voor de openstelling van bossen door particuliere boseigenaren bestaat wel een regeling: hiervoor wordt $€ 2$ per strekkende meter pad betaald (met een maximum van $€ 50$ per ha bos).

Toezicht en onderhoud van de wegen

Op alle wegen die door het publiek mogen worden gebruikt heeft de gemeente de politiebevoegdheid. De inrichtingsbevoegdheid van de gemeente, zoals het onderhoud van de paden en de bewegwijzering, beperkt zicht tot de buurtwegen, de gemeentewegen en de publiekrechtelijke erfdienstbaarheden. Op wegen in feitelijke toestand van openbare weg en private wegen is de particuliere eigenaar verantwoordelijk voor de inrichting. De Vlaamse overheid heeft een polis burgerlijke aansprakelijkheid afgesloten om de schade te dekken die bezoekers kunnen oplopen wanneer zij van wegen in feitelijke toestand van openbare weg en private wegen gebruik maken. 


\section{Nieuw decreet in Wallonië}

Het parlement van Wallonië heeft in 2014 een nieuw decreet op de gemeentewegen goedgekeurd. Dit decreet vervangt (voor het Waalse Gewest) de Wet op de Buurtwegen uit 1841. Wijzigingen ten opzichte van de oude wet zijn onder meer:

- Alle trage wegen in Wallonië moeten in een wegenatlas worden opgenomen.

- Na tien jaar openbaar gebruik (in plaats van 30 jaar) kan een weg in een gemeenteweg overgaan in het geval er een rooilijnplan (i.e. de grens tussen de openbare weg en de aangrenzende eigendommen) is opgemaakt.

- Er komt een wegenreserve van wegen die niet meer door het publiek worden gebruikt. Ze worden dan niet meer door de gemeente onderhouden. Wel blijven ze juridisch bestaan en kunnen ten allen tijde weer worden geactiveerd.

- Particulieren zoals boeren en terreineigenaren kunnen met de gemeente een contract voor 29 jaar afsluiten om hun particuliere weg een bestemming als gemeenteweg te geven. Na die 29 jaar kan het contract desgewenst na één dag onderbreking worden verlengd.

- Natuurlijke of rechtspersonen kunnen een verzoek tot wijziging of afschaffing van een gemeenteweg indienen bij de gemeenteraad, die de bevoegdheid heeft om daar over te beslissen.

\subsection{Leerpunten voor Nederland}

Uit de Belgische organisatie van wandelpaden kan een aantal leerpunten voor Nederland worden afgeleid:

1. Het vastleggen van wegen in een wegenatlas is een goede manier om een overzicht te krijgen van bestaande paden met publieke toegang. Met zo'n wegenatlas kan ook worden voorkomen dat paden 'verdwijnen' door opzettelijke afsluiting door de eigenaar of achterstallig onderhoud.

2. Het afsluiten van een contract met de overheid - zoals bijvoorbeeld de gemeente of de provincie waarin wordt bepaald dat een particuliere weg, bijvoorbeeld een boerenlandpad, gedurende een meerjarige periode een openbare weg wordt, waarbij de overheid verantwoordelijk is voor het onderhoud ervan.

3. Als boeren hun pad vrijwillig voor het publiek openstellen blijkt dat zij vaak behoefte hebben om afspraken te maken over het voorkomen van publiekrechtelijke erfdienstbaarheid van doorgang na verjaring.

4. Het afsluiten van een polis burgerlijke aansprakelijkheid door de overheid - zoals bijvoorbeeld de provincie of het Rijk - kan particuliere eigenaren stimuleren om hun paden voor het publiek open te stellen. In dat geval zijn de particuliere eigenaren niet aansprakelijk voor de schade die bezoekers oplopen tijdens het gebruik van hun paden. 


\section{Duitsland}

\subsection{Organisatie}

Natuurlijke landschappen voor iedereen toegankelijk

Volgens de algemene wetgeving in Duitsland zijn wegen en paden, ook als deze in privébezit zijn, voor iedereen toegankelijk. Die wetgeving vindt zijn oorsprong in het 'Betretungsrecht' (betredingsrecht). In het betredingsrecht wordt gesteld dat iedereen het recht moet hebben natuurlijke landschappen ('freien Landschaft') te kunnen betreden, ongeacht of het om publiek of privaat eigendom gaat. Bij natuurlijke landschappen gaat het onder meer om:

- wandelwegen door bossen en alpenweiden

- bossen

- gronden die dichtbij of naast bergen, meren en rivieren liggen

- landbouwgronden die op dat moment niet als landbouwgrond worden gebruikt

- landbouwpercelen in de herfst na de oogst.

In de praktijk is het niet altijd duidelijk waar de grens tussen het 'freien Landschaft' en het niet te betreden privéterrein ligt. Wel is duidelijk dat alle bebouwde oppervlakte en duidelijk herkenbaar ordelijke percelen niet tot het 'freien Landschaft' behoren. Bezoekers van het 'freien Landschaft' dienen het eigendom te respecteren, mogen geen schade toebrengen aan zeldzame flora, fauna en op het veld staande gewassen, en het vee niet verontrusten.

\section{Betreding 'freien Landschaft' voor eigen risico}

Er zijn in Duitsland geen specifieke regelingen voor vergoedingen aan boeren voor het openstellen van wandelpaden over boerenland. In de Duitse wetgeving is wel duidelijk opgenomen dat betreding van paden in het 'freien Landschaft' door recreanten voor eigen risico is en dat de eigenaar van de paden of gronden niet aansprakelijk kan worden gesteld voor zorgtaken, ongelukken of verkeersproblemen. Het 'Betretungsrecht' legt eigenaren van paden geen enkele onderhoudsverplichting op. Wel kan de Staat eigenaren verplichten de paden door periodiek maai- en/of snoeiwerk zichtbaar te houden, zodat er gebruik van kan worden gemaakt.

\section{Aanleg nieuwe wandelpaden in onderling overleg}

De aanleg van nieuwe wandelpaden dient in onderling overleg van belanghebbenden, zoals buurtbewoners, gemeenten, districten, wandelorganisaties en lokale boeren, te worden geregeld. Bij die onderhandelingen wordt ook gesproken over de wijze van de financiering van de aanleg van een wandelpad en de eventuele jaarlijkse vergoedingen voor het onderhoud.

\section{Deelstaten kunnen iets afwijken van algemene Duitse wetgeving}

De wetgeving in de verschillende Duitse deelstaten (de 16 Länder) kan door algemene maatregelen van bestuur soms iets afwijken van de algemene Duitse wetgeving. Zo heeft Beieren bijvoorbeeld wettelijk bepaald dat er een voorkeursrecht is voor gemeenten en voor de deelstaat Beieren om gronden die aan een meer liggen te mogen kopen. Dit is gedaan om het grondwettelijk recht dat iedereen voldoende toegang heeft tot bergen, meren en wateren te borgen. Per deelstaat kunnen er verschillende regels gelden voor het afsluiten van een particuliere weg voor het publiek; dat kan bijvoorbeeld worden toegestaan als aantoonbaar is dat er meerdere malen schade is toegebracht of als natuurwaarden in het gedrang zijn. 


\subsection{Leerpunten voor Nederland}

Uit de Duitse organisatie van wandelpaden kan een aantal leerpunten voor Nederland worden afgeleid:

1. Het hanteren van een gedragscode voor bezoekers van paden maakt voor zowel de eigenaren als de recreanten duidelijk wat wel en niet mag tijdens het gebruiken van een pad.

2. Door eigenaren alleen te verplichten het pad door periodiek maai- en/of snoeiwerk zichtbaar te houden zonder verdere onderhoudsverplichting kunnen de kosten van het openstellen van het pad voor het publiek worden geminimaliseerd.

3. Zorg dat betreding van particuliere paden door recreanten voor eigen risico is en de eigenaar van de paden niet aansprakelijk kan worden gesteld voor zorgtaken, ongelukken of verkeersproblemen. 


\section{$4 \quad$ Frankrijk}

\subsection{Organisatie}

Sinds 1959 hebben de Franse gemeenten de bevoegdheid over twee soorten wegen: de gemeentewegen ('voies communales') en de landelijke wegen ('chemins rureaux'). Wandelpaden vallen onder deze laatste categorie. De landelijke wegen zijn toegankelijk voor het publiek. Naast deze landelijke wegen zijn er nog twee andere soorten wandelpaden in Frankrijk: voetpaden naar bedrijfsactiviteiten en privé-voetpaden in gemeenschappelijk eigendom. Deze drie typen wandelpaden worden hieronder toegelicht:

1. Landelijke wegen

De landelijke wegen zijn meestal oude verbindingswegen tussen dorpen en buurtschappen. Ze zijn in bezit van de lokale gemeenschap en worden door hen en ook anderen gebruikt. De landelijke wegen zijn opgenomen in het kadaster. Het toezicht en onderhoud van deze paden is een gemeentelijke taak. De gemeente is echter niet verplicht om een landweg ook daadwerkelijk te onderhouden. Alleen als de gemeente ervoor kiest om een landelijke weg te onderhouden, is zij aansprakelijk voor ongevallen op deze weg.

2. Voetpaden naar bedrijfsactiviteiten

Deze paden zijn doorgaans in eigendom bij degenen die deze paden voor hun bedrijf gebruiken (bijvoorbeeld voor landbouw, tuinbouw, visserij enzovoort). Ze zijn alleen toegankelijk na toestemming van de eigenaar. De eigenaar kan die toestemming te allen tijde intrekken.

3. Privé-voetpaden in gemeenschappelijk eigendom

Deze paden bieden de gezamenlijke eigenaren/gebruikers toegang tot een openbare weg. Veel van deze paden zijn openbaar toegankelijk door de medewerking van de gezamenlijke eigenaren. De kosten van het onderhoud komen voor rekening van de particuliere eigenaren. Met het oog op de veiligheid of om het verkeer te regelen heeft de burgemeester van een gemeente de bevoegdheid om paden te openen of juist te sluiten (bijvoorbeeld voor natuurbescherming). Ook de eigenaren van het pad hebben het recht om het pad af te sluiten voor het publiek.

Departementaal plan van wandelwegen en rondwandelingen

De Franse departementen hebben een Plan Départemental des Intenéraires de Promenade de Randonnées (PDIPR), waarin wandelingen over landelijke wegen zijn opgenomen. Om de instandhouding van deze wandelingen te garanderen zijn gemeenten, in het geval zij een landelijke weg die deel uitmaakt van een wandeling willen afschaffen, verplicht om met een alternatief traject te komen. Dat alternatieve traject kan een andere landelijke weg zijn maar ook een private weg. In dat laatste geval bestaat echter de kans dat de eigenaren op enig moment besluiten om de weg af te sluiten voor publiek gebruik, waardoor de handhaving van de wandeling in gevaar kan komen als de gemeente niet op de hoogte is van de afsluiting.

Wandelpaden met erfdienstbaarheid van openbare doorgang

Frankrijk heeft twee soorten wandelpaden met een erfdienstbaarheid van openbare doorgang, ongeacht of ze al dan niet over particuliere paden gaan: een wandelpad langs de Franse kust en alle voet- en jaagpaden langs rivieren en kanalen. Daarnaast zijn alle Franse staatsbossen en alle private boswegen en bergweiden, die niet zijn afgesloten, voor het publiek toegankelijk. Ook zijn er in Frankrijk tal van niet langer gebruikte spoorwegverbindingen herbestemd als wandelpad (de zogenaamde voies vertes).

\section{Aanleg nieuwe wandelpaden in onderling overleg}

Er zijn in Frankrijk geen landelijke regelingen voor het aanleggen van nieuwe wandelpaden. Voor lokale wandelpaden ligt de verantwoordelijkheid bij de gemeenten; gaat het om nieuwe langeafstandwandelpaden dan is het departement of het landelijke comité van de departementen verantwoordelijk. De aanleg van wandelpaden gebeurt in overleg met de lokale grondgebruikers en eventueel de gemeenten. 


\subsection{Leerpunten voor Nederland}

Uit de Franse organisatie van wandelpaden kan een aantal leerpunten voor Nederland worden afgeleid:

1. Het maken van een overzicht met wandelpaden met een publieke erfdienstbaarheid van doorgang, zoals een kustpad, voet- en jaagpaden langs rivieren en kanalen, en voies verts, schept duidelijkheid over die wandelpaden waarvan de openbare toegang buiten kijf staat.

2. Het maken van een provinciaal overzicht van wandelwegen en rondwandelingen, waarvoor wordt afgesproken dat ze altijd voor het publiek toegankelijk moeten blijven, ook als gedeeltes van de route worden verlegd naar paden van andere eigenaren. 


\section{$5 \quad$ Verenigd Koninkrijk}

\section{$5.1 \quad$ Organisatie}

Het Verenigd Koninkrijk (VK) kent een lange traditie van 'rights of way' en 'right to roam', die de openbare toegankelijkheid van wandelpaden en landerijen regelt. Omdat in de loop van de twintigste eeuw steeds meer landeigenaren voetpaden afsloten, ontstond er behoefte om dit ongeschreven recht om te zetten in wetgeving. Mede door toedoen van wandelorganisaties zoals de Ramblers Association werd de National Parks and Access to the Countryside Act in 1949 van kracht. Deze wet bepaalde dat alle counties/regio's een kaart met een overzicht van alle publieke wegen moesten opstellen, met als doel een wettelijk document met een overzicht van alle publieke (voet)paden in het VK.

\section{Countryside and Rights of Way 2000 in Engeland en Wales}

Ondanks deze eerste Countryside Act bleef het recht van overpad ook in de tweede helft van de twintigste eeuw niet onomstreden. In 2000 werd voor Engeland en Wales de Countryside and Rights of Way 2000 aangenomen. Deze nieuwe wet omvat onder andere een (beperkt) 'right to roam' die het publiek het recht geeft om - onder voorwaarden - te struinen over 'wild and open' platteland zoals bergen, heide, veengebieden en 'commons'. Wandelaars hoeven daarbij niet op de paden te blijven. Daarnaast biedt deze wetgeving een verdere versterking van het rights of way-principe waarbij wandelaars gebruik kunnen blijven maken van (geregistreerde) publieke wandelpaden, en richtlijnen om obstructie van wandelpaden (door bijvoorbeeld beplanting) tegen te gaan. Ook regelt de wet een regelmatige actualisatie van het overzicht van alle publieke paden.

\section{Land Reform (Scotland) Act 2003}

In Schotland zijn de rechten voor publieke toegang tot paden en landerijen nog uitgebreider. Daar is de oude traditie van een universele toegang tot het (platte)land vastgelegd in de Land Reform (Scotland) Act 2003. Deze act bevestigt zowel het recht om op het land te zijn voor recreatieve, educatieve en sommige andere doeleinden als het recht van overpad. Een voorwaarde daarbij is wel dat deze rechten op een verantwoorde manier dienen te worden uitgeoefend zoals gespecificeerd in de Scottish Outdoor Acces Code. Die code is gebaseerd op drie principes:

1. respect voor de belangen van anderen

2. zorg voor het milieu

3. het nemen van verantwoordelijkheid voor de eigen acties. De code is aangenomen door de ministers en het parlement van Schotland.

Over het algemeen wordt de Countryside and Rights of Way uit 2000 gezien als een grote overwinning voor de (lobby-)organisaties die strijden voor de toegankelijkheid van het platteland. De voorstanders hebben met deze wet een heel belangrijk instrument in handen gekregen om het recht van overpad te behouden. Dat neemt niet weg dat de strijd over de toegankelijkheid van het platteland nog steeds zo nu en dan oplaait, vooral tussen (sommige) landeigenaren aan de ene kant en wandelaars(organisaties) aan de andere kant. Hoewel sommige landeigenaren de rechten van de wandelaars en ook hun meerwaarde voor de toeristische industrie erkennen proberen anderen nog steeds om deze rechten ter discussie te stellen en de toegang te beperken.

Vier soorten wandelpaden in het VK

1. public footpaths (openbare voetpaden) Deze zijn alleen toegankelijk voor wandelaars.

2. public bridleways (openbare ruiterpaden) Deze zijn toegankelijk voor wandelaars, ruiters en fietsers.

3. restricted byways (zijwegen met beperkingen) Deze paden zijn toegankelijk voor wandelaars, ruiters, menners en fietsers.

4. byways open to all traffic (zijwegen voor alle verkeer)

Dit zijn brede veldwegen die ook geschikt zijn voor gemotoriseerde voertuigen maar die niet zijn ingericht als verkeerswegen. 
Beheer en onderhoud van de wandelpaden

Het beheer van de wandelpaden - ook als deze over particuliere grond lopen - is per district of county in handen van de Highways Authorities. Deze autoriteit zorgt ervoor dat de kaart met alle paden in het district/county bij wordt gehouden en dat de paden worden bewegwijzerd. Ook kunnen zij alle belemmeringen van publieke doorgang van een pad verwijderen. De kosten daarvan komen voor rekening van de eigenaar van het pad. Eigenaren zijn verplicht om het pad te onderhouden. Voor het plaatsen van poorten, overstapjes en draaipoortjes hebben eigenaren toestemming van de Highways Authorities nodig. Doorgaans vergoeden de Highways Authorities een kwart van de kosten van het onderhoud van het pad aan de eigenaar. Voor de openstelling van het pad ontvangt de eigenaar geen vergoeding.

\section{Aanleg nieuwe wandelpaden}

Nieuwe wandelpaden kunnen ontstaan als de Highways Authorities en/of het ministerie van DEFRA een pad aanwijst of aanlegt waarop het publiek toegang heeft, of als een particuliere eigenaar een particulier pad openstelt voor publieke toegang.

\subsection{Leerpunten voor Nederland}

Uit de Britse organisatie van wandelpaden kan een aantal leerpunten voor Nederland worden afgeleid:

1. Een landelijke of provinciale atlas met een overzicht van publiek toegankelijke paden biedt duidelijkheid over welke paden er zijn en bemoeilijken het laten verdwijnen van paden.

2. Het hanteren van een toegangscode voor de paden zoals de Scottish Outdoor Acces Code biedt duidelijkheid over de gedragsregels voor gebruikers van publieke paden. Een dergelijke code kan worden opgesteld door de overheid, een natuur- en landschapsorganisatie of een wandelorganisatie.

3. Het aanwijzen van een gemeentelijke of provinciale instantie zoals de Highways Authorities die verantwoordelijk is voor de bewegwijzering van de paden en die toeziet op het onderhoud van de paden door de eigenaren vergemakkelijkt de herkenbaarheid en de toegankelijkheid van de paden. 


\section{$6 \quad$ Besluit}

In deze notitie is nagegaan hoe de toegankelijkheid van wandelpaden in beheer bij boeren en andere particuliere eigenaren is georganiseerd in België, Duitsland, Frankrijk en het Verenigd Koninkrijk en wat Nederland daarvan kan leren voor de organisatie van de toegang tot de Nederlandse wandelpaden. We besluiten deze notitie met een aantal conclusies en leerpunten.

\section{Conclusies}

1. Geen van de onderzochte landen kent een regeling waarbij boeren een vergoeding krijgen voor de openstelling van wandelpaden over hun land. De publieke toegankelijkheid van boerenlandpaden en andere wandelpaden in eigendom van particulieren wordt daar op andere manieren geregeld, zoals het openstellen van paden op basis van verplichting of vrijwilligheid.

2. In alle onderzochte landen worden de regelingen rond de openbare toegankelijkheid van paden geflankeerd door aanvullende regelingen over bijvoorbeeld het onderhoud van de paden, een gedragscode voor de gebruikers van de paden, toezicht op de paden en registratie van paden.

3. Uit de ervaringen in de onderzochte landen blijkt dat ondanks het bestaan van uitvoerige wetgeving die de publieke toegang tot wandelpaden en landerijen regelt, er altijd particuliere eigenaren zullen blijven die de publieke doorgang op de paden over hun land proberen te belemmeren.

Leerpunten voor de organisatie van publiek toegankelijke wandelpaden Nederland

Op basis van voorbeelden van de organisatie van wandelpaden in België, Duitsland, Frankrijk en het VK hebben we in deze notitie per land een aantal leerpunten voor Nederland geïdentificeerd. Deze blijken elkaar deels te overlappen; voor een ander deel kunnen ze worden gecombineerd. Op die manier komen we tot de volgende zes leerpunten:

1. Het vastleggen van wegen in een wegenatlas is een goede manier om een overzicht te krijgen van bestaande paden met publieke toegang. Met zo'n wegenatlas kan ook worden voorkomen dat paden 'verdwijnen' door opzettelijke afsluiting door de eigenaar of achterstallig onderhoud (alle onderzochte landen).

2. Het maken van een provinciaal overzicht van wandelwegen en rondwandelingen, waarvoor wordt afgesproken dat ze altijd voor het publiek toegankelijk moeten blijven, ook als gedeeltes van de route worden verlegd naar paden van andere eigenaren (Frankrijk).

3. Het aanwijzen van een gemeentelijke of provinciale instantie zoals de Highways Authorities die verantwoordelijk is voor de bewegwijzering van de paden en die toeziet op het onderhoud van de paden door de eigenaren vergemakkelijkt de herkenbaarheid en de toegankelijkheid van de paden (VK).

4. Voor het minimaliseren van de kosten van het openstellen van een pad voor de eigenaar bestaan verschillende mogelijkheden. Er kan een contract tussen een particuliere eigenaar van een pad en de overheid (bijvoorbeeld de gemeente of de provincie) worden afgesloten waarin wordt bepaald dat een particuliere weg, bijvoorbeeld een boerenlandpad, gedurende een meerjarige periode een openbare weg wordt, waarbij de overheid verantwoordelijk is voor het onderhoud ervan (België). Een andere manier om de kosten voor het onderhoud van het pad te beperken is om eigenaren alleen te verplichten het pad door periodiek maaien en/of snoeien zichtbaar te houden (Duitsland).

5. Om te voorkomen dat de eigenaar van een particulier pad aansprakelijk wordt gesteld voor schade die bezoekers oplopen tijdens het gebruik van hun pad kunnen verschillende regelingen worden getroffen. De overheid kan bijvoorbeeld een polis burgerlijke aansprakelijkheid afsluiten waardoor particuliere eigenaren niet aansprakelijk zijn voor die schade (België). Een andere mogelijkheid is om te bepalen dat betreding van particuliere paden door recreanten voor eigen risico is en dat de eigenaar van de paden niet aansprakelijk kan worden gesteld voor zorgtaken, ongelukken of verkeersproblemen (Duitsland).

6. Het hanteren van een gedragscode voor bezoekers van paden maakt voor zowel de eigenaren als de recreanten duidelijk wat wel en niet mag tijdens het gebruiken van een pad. Een dergelijke code kan worden opgesteld door de overheid, een natuur- en landschapsorganisatie of een wandelorganisatie (Duitsland, VK). 


\section{Literatuur, websites en geraadpleegde personen}

Referenties

Clays, S. (2014). Handboek tragewegenrecht; Gent, Trage Wegen.

Conseil Général des Cotes d’Armor (2008). Guide Juridique; La législation des chemins de randonnée ; Saint Brieuc.

Deutschen Wanderverbandes (2015). Infosammlung Natursport; Allgemeine und rechtliche Aspekte für die Ausübung von Natursportenarten und die Herstellung begleitender Infrastruktur; Kassel.

Fédération Française de la Randonnée Pédestre (2016). Guide du droit des chemins; Parijs.

Haeften, S.C.D. van (2015). Openstellingsmogelijkheden voor boerenland in de provincie Utrecht; Delft, Afstudeeronderzoek Landscape and Environment Management, 30 november.

Rijk, P.J. (2004). Advisering/toetsing vergoedingen voor het aanleggen van wandelpaden in de Haarlemmermeer; Adviesrapport aan het projectbureau Haarlemmermeer Groen; Den Haag, LEIVensterrapport.

Rijk, P.J. (2005). Wandelpaden op land- en tuinbouwbedrijven; animo, mogelijkheden en vergoedingssysteem; Den Haag, LEI-rapport 4.05.03.

Geraadpleegde websites

www. ffrandonnee.fr

http://geo.vlaamsbrabant.be/tragewegen

www.klompenpaden.nl

www.landschapsbeheerzeeland.nl

www.legislation.gov.uk/ukpga/Geo6/12-13-14/97

www. nationaltrust.org.uk/features/what-is-a-public-right-of-way

www.naturschutzrecht-online.de

www. natursportplaner.de

www. natuurenbos.be

www. outdooraccess-scotland.com/The-Act-and-the-Code/introduction

www.provinciegroningen. $\mathrm{nl}$

www.ramblers.org.uk/advice/rights-of-way-law-in-england-and-wales.aspx

www.theguardian.com/commentisfree/2015/jul/10/guardian-view-on-rambling-right-to-roam-is-

precious-freedom

www.tragewegen.be

http://tyrandofree.fr/guide juriduque

www.wanderbares-deutschland.de

https://en.wikipedia.org/wiki/Freedom_to_roam\#United_Kingdom 


\section{Geraadpleegde personen}

België: $\quad$ Trage Wegen, Gent (Steven Clays, mailwisseling)

Duitsland: Deutscher Wanderverband, Kassel (Erik Neumeier, telefonisch)

Frankrijk: Féderation Française de la Randonnée Pédestre, Parijs (telefonisch)

Nederland: Wandelnetwerk Nederland, Amersfoort (Ankie van Dijk en Ben Helming, gesprek)

Landschapsbeheer in Gelderland (directeur Arjan Vriend, mailwisseling en Erik van Eek, telefonisch)

Landschapsbeheer Zeeland (directeur Foort Minnaard, telefonisch)

VK: $\quad$ Alterra Wageningen UR (Lawrence Jones-Walters, gesprek) 


\section{Bijlage 1 Motie Jacobi c.s. (33 888 nr. 8)}

\section{8}

Nr. 8

\author{
Initiatiefnota van de leden Smaling, Hoogland en \\ de Rouwe: "Een stap vooruit, voorstellen voor \\ de uitbouw en betere benutting van het \\ Nederlandse wandel- en fietsnetwerk"
}

MOTIE VAN HET LID JACOBI C.S.

Voorgesteld tijdens het Notaoverleg van 19 januari 2015

De Kamer,

gehoord de beraadslaging,

overwegende dat veel aantrekkelijke wandelroutes gebruikmaken van onverharde paden, die veelal in beheer zijn bij particulieren;

van mening dat de boerenlandpadregeling niet optimaal functioneerde en dat de regelingen voor landgoedeigenaren in de Natuurschoonwet op punten verbeterd kunnen worden;

verzoekt de regering, mede aan de hand van buitenlandse voorbeelden en de resultaten van de evaluatie van de Natuurschoonwet 1928 , te onderzoeken in welke vorm de toegankelijkheid van paden in beheer bij boeren en andere particuliere eigenaren het beste in Nederland georganiseerd kan worden;

verzoekt de regering tevens, zich samen met het Interprovinciaal Overleg (IPO) in te spannen voor het zo veel mogelijk uniformeren en structureel maken van regelingen op dit terrein;

verzoekt de regering voorts, de voorwaarden bij de regelingen beter uit te werken ten bate van logische doorgaande routes waarbij de toegankelijkheid niet nodeloos beperkt wordt,

en gaat over tot de orde van de dag.

Jacobi

Bashir

Van Helvert 
Wageningen Economic Research Postbus 29703

2502 LS Den Haag

T 0703358330

Ecommunications.ssg@wur.nl

www.wur.nl/economic-research

Wageningen Economic Research NOTA

2016-095
De missie van Wageningen University \& Research is 'To explore the potential of nature to improve the quality of life'. Binnen Wageningen University \& Research bundelen Wageningen University en gespecialiseerde onderzoeksinstituten van Stichting Wageningen Research hun krachten om bij te dragen aan de oplossing van belangrijke vragen in het domein van gezonde voeding en leefomgeving. Met ongeveer 30 vestigingen, 5.000 medewerkers en 10.000 studenten behoort Wageningen University \& Research wereldwijd tot de aansprekende kennisinstellingen binnen haar domein. De integrale benadering van de vraagstukken en de samenwerking tussen verschillende disciplines vormen het hart van de unieke Wageningen aanpak. 


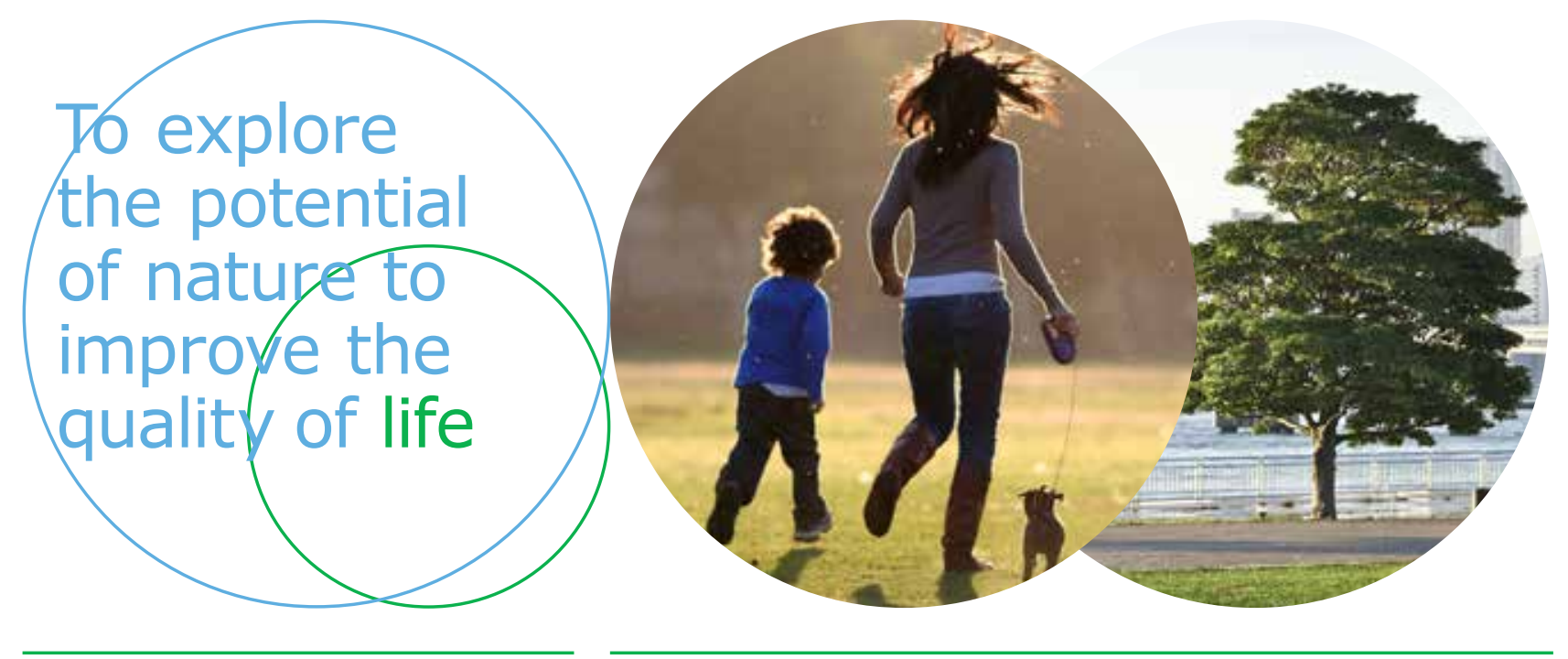

Wageningen Economic Research Postbus 29703

2502 LS Den Haag

E communications.ssg@wur.nl

$\mathrm{T}+31(0) 703358330$

www.wur.nl/economic-research

De missie van Wageningen University \& Research is 'To explore the potential of nature to improve the quality of life'. Binnen Wageningen University \& Research bundelen Wageningen University en gespecialiseerde onderzoeksinstituten van Stichting Wageningen Research hun krachten om bij te dragen aan de oplossing van belangrijke vragen in het domein van gezonde voeding en leefomgeving. Met ongeveer 30 vestigingen, 5.000 medewerkers en 10.000 studenten behoort Wageningen University \& Research wereldwijd tot de aansprekende kennis-

Nota 2016-095 instellingen binnen haar domein. De integrale benadering van de vraagstukken en de samenwerking tussen verschillende disciplines vormen het hart van de unieke Wageningen aanpak. 